\title{
Infection of grain crops with fungi of the genus Fusarium
}

\author{
N.Yu. Zargaryan", A.Yu. Kekalo, and V.V. Nemchenko \\ FSBSI "Ural Federal Agrarian Scientific Research Centre, Ural Branch of the Russian Academy of \\ Sciences", Belinskogo Str., 112a, 620142, Yekaterinburg, Russia
}

\begin{abstract}
The widespread production of grain crops and the rejection of the classical technology of tillage led to a noticeable increase in the prevalence and harmfulness of phytopathogens. First of all, this applies to facultative parasites with a wide specialization - Bipolaris, Fusarium, as well as secondary fungi from the genus Alternaria, Cladosporium, Penicillium, etc. At the same time, there is a change of dominance among these species. The predominant niche is occupied by fungi of the genus Fusarium, instead of species of the genus Bipolaris. The infestation of not only the seed material with this pathogen, but also the root system requires the selection of approaches to reduce this pathogen development. The use of modern fungicides with chemical or biological substances in their composition can protect plants from the pathogen and affect yield.
\end{abstract}

\section{Introduction}

One of the main conditions for obtaining a high grain yield is a high-quality seed material. Infection of seeds with pathogens is one of the reasons for the decrease in this indicator. Pathogens cause the development of root rot, the death of shoots and sprouts, and a decrease in productive bushiness. As a result, all this leads to a decrease in crop yield and a deterioration in the technological qualities of grain.

Phytopathogens in the seed material can be preserved and transmitted, both inside and on the surface of the seeds by means of the mycelium of the fungus or spores, or as an admixture with seeds. It is possible to detect a hidden infection and identify pathogens with the help of a phytopathological examination of the seed material.

According to the Rosselkhozcenter in recent years, the most harmful fungi are of the genus Fusarium spp. The diseases caused by them cause great harm to cereals. When infected with this pathogen, the vascular system and plant tissues are affected, as a result, the roots and seeds rot, damage to the ears. Infection of plants can occur during the growing season [1].

The germination power and germination capacity is reduced when they are infected with pathogenic fungal species. The pathogen harmfulness depends on the localization of the mycelium and on the number of affected seeds. In case when grain is used for food or feed purposes, not only the degree of infection is important, but the type of pathogens. Many

* Corresponding author: natashazarg@yandex.ru 
fungi in the process of their vital activity form mycotoxins that pose a danger to human and animal health. Thus, fungi of the genus Fusarium spp. produce various mycotoxins, one of which is desoxynivalenol (DON) and T-2 toxin, for which strict limits are set for their content in grain and its processed products $-0.7-2$ and $0.1 \mathrm{mg} / \mathrm{kg}$, respectively [2].

Grains infected with fusarium can differ very much from healthy ones, both in appearance and in chemical composition, structural and mechanical properties, enzymatic activity and nutritional value [3].

One of the main pathogens of root rot of cereals are fungi of the genus Fusarium spp. The development of this disease is most pronounced in the germination phase, but it can also develop in later phases of plant development, causing thinning of the basal part of the stem.

The disease of shoots grown from infected grain manifests in the form of rotting of the roots and collet. The affected tissues turn brown, the stem becomes thinner, the leaves turn yellow. Soon the plant withers and dies. Infection mainly occurs in foci through the soil. Weakened plants are most susceptible to the disease [1].

The noticeable development of root rot is determined by the high saturation of crop rotations with susceptible crops and monocultures, provoking the accumulation of pathogens, and low suppressiveness of soils, contributing to the long-term survival and preservation of dormant structures $[4,5]$.

One of the main methods of plant protection from root rot is the pre-sowing treatment of seed material with fungicides. A large set of preparations with a different spectrum of action is presented on the market [6]. Nevertheless, not all of them act equally effectively on a certain phytopathogen. Therefore, the study of the influence of various groups of fungicides on fungi of the genus Fusarium spp.is relevant. Especially against the background of an increase in plant infection with this pathogen in the conditions of the Trans-Urals.

The purpose of the study is to establish the effectiveness of various groups of fungicides for seed treatment against fungi of the genus Fusarium spp.

\section{Materials and methods}

The research was carried out in the Kurgan Research Institute of Agriculture - branch of FSBSI UrFASRC, Ural Branch of the Russian Academy of Sciences in the laboratory of plant growth and protection regulators within the framework of the State Task of the Ministry of Science and Higher Education in the direction "To improve the system of adaptive landscape farming for the Ural region and create new-generation agricultural technologies based on minimizing soil treatment, crop rotation diversification, rational use of pesticides and biological products, preservation and improvement of soil fertility and to develop an information and analytical complex of computer programs that provides innovative management of the farming system".

Phytoexpertize of seeds was carried out using filter paper. On two layers of moistened paper, one sample of seeds (100 pcs.) was laid out with the embryos down. From above, the seeds were covered with a strip of paper of the same size, then the strips were rolled up and placed in an upright position in a glass of water. After 7-14 days, the contamination of the seed material was determined by microscopy.

To conduct a mycological analysis on the organs of spring wheat of the Omskaya 36 variety, plant samples were taken in the tillering and earing phase, followed by incubation on the Czapek's medium. Determinants were used to identify microscopic fungi $[7,8]$.

The effectiveness of protectants against fungi of the genus Fusarium spp. was determined on the PDAM medium by the diameter of the mycelium-free zone and the indicator "preparation activity" (A). If the preparation activity equals to 1 , the fungicide is 
ineffective, i.e. the growth delay zone is not formed, if it equals to 2-3, then the activity of the preparation is low, 4 - average, and if $\mathrm{A} \geq 5$ - high $[9,10]$.

Field tests of the effectiveness of seed protectants on spring wheat were carried out in the second field of the grain-fallow crop rotation. Sowing was carried out by a disk seeder, the system of soil preparation is minimal. The wheat variety - Omskaya 36. Seed treatment was carried out manually with a working solution consumption of $10 \mathrm{l} / \mathrm{t}$.

\section{Results and discussion}

Phytoexpertize of spring wheat seed material determined a complex of phytopathogens prevailing on seeds, which was represented by fungi of the genera Fusarium Link., Alternaria Nees, Bipolaris sorokiniana Shoemaker (Fig. 1). On average, during 10 years of research, fungi of the genus Alternaria prevailed on seeds, both in conditions of satisfactory humidification and in dry periods. Colonization of grain of spring wheat Bipolaris sorokiniana Sacc. Shoem., was insignificant in contrast to Fusarium spp., where the occurrence of this fungus was 9.2-16.4\%. The development of the considered phytopathogens depended on weather conditions, with a decrease in humidity and an increase in temperature, their number decreased with the exception of the fungus Bipolaris sorokiniana Sacc. Shoem., the most favorable conditions for it were moderate-arid conditions of the growing season (the hydrothermal coefficient was 0.7-0.9).

Over the past decade, there has been a change in the microbial community of the surface of wheat seeds obtained in the Trans-Urals. Thus, among the most harmful pathogens, the leading place was taken by fungi of the genus Fusarium spp., shifting Bipolaris sorokiniana to the background. This was facilitated by the change in the temperature regime, the transition to minimizing tillage and the predominance of cereals in crop rotations.

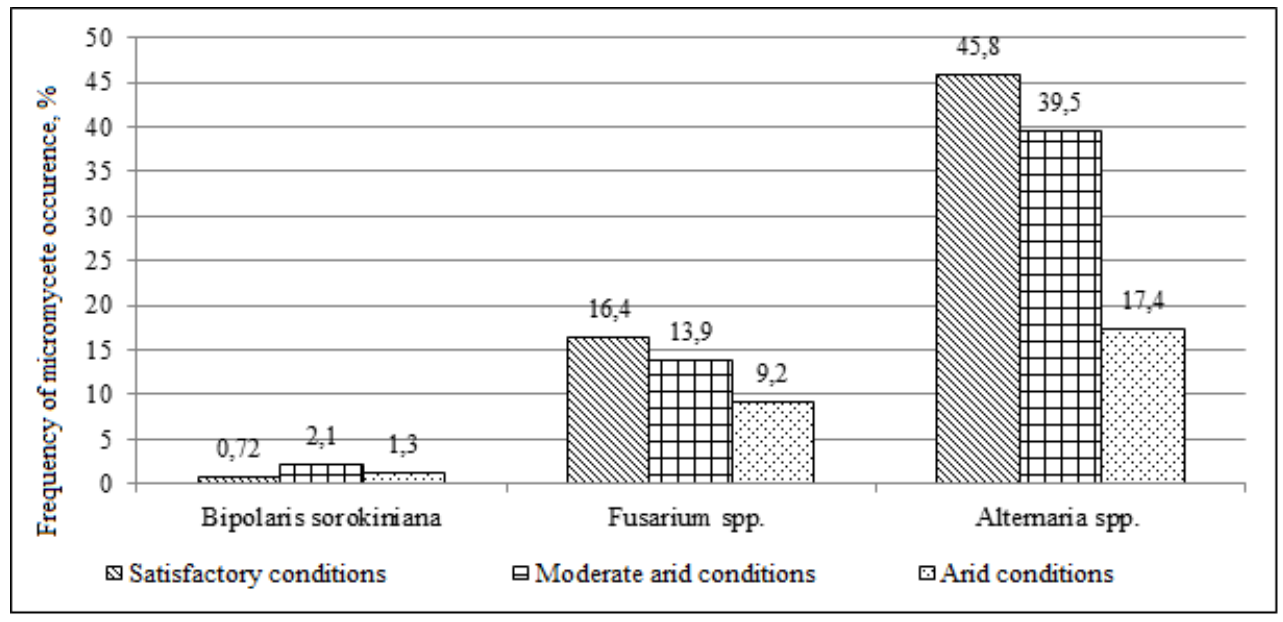

Fig. 1. The occurrence of pathogenic micromycetes on spring wheat seeds, depending on the humidity of the growing season.

The ecological niche of fungi of the genus Fusarium spp. on cereals is quite wide, affecting aboveground, underground, generative organs and soil, which makes it possible to maintain a consistently high population. According to Siberian scientists [11, 12], annually on grain crops more than 10 species of the genus Fusarium spp. parasitize, among which the most common are F. equiseti (Corda)Sass., F. oxysporum (Schleht) Snyd. et Hans, F. solani, F. sporotrichoidis Sherb. 
According to the results of our study, F. oxysporum (Schleht) Snyd, F. graminearum Schwabe, F. sporotrichoidis Sherb. received the main distribution on spring wheat, both in the tillering phase and in the phase of milk-wax ripeness. (figure 2.3). In the tillering phase, the number and diversity of species was significantly higher than in the milk-waxy ripeness phase. This was facilitated by weather conditions at the beginning of the growing season of the crop favorable for pathogen development.

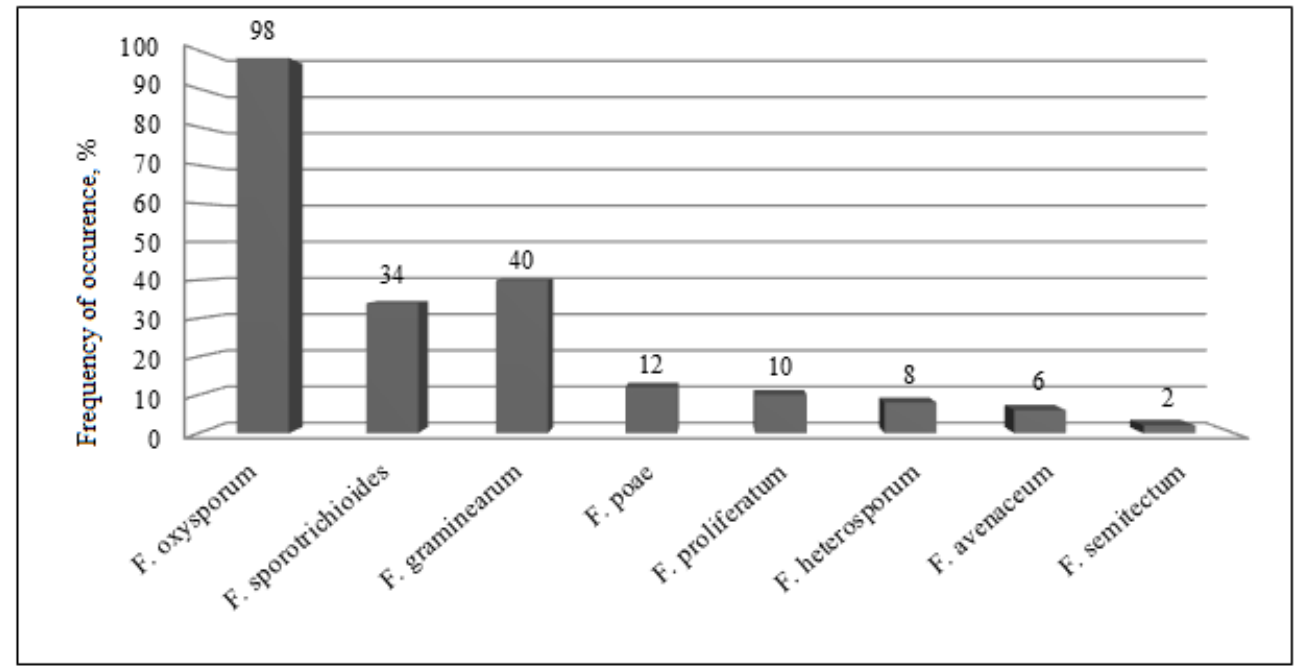

Fig. 2. The ratio of species of fungi of the genus Fusarium spp. on underground and near-ground organs of wheat in the tillering phase.

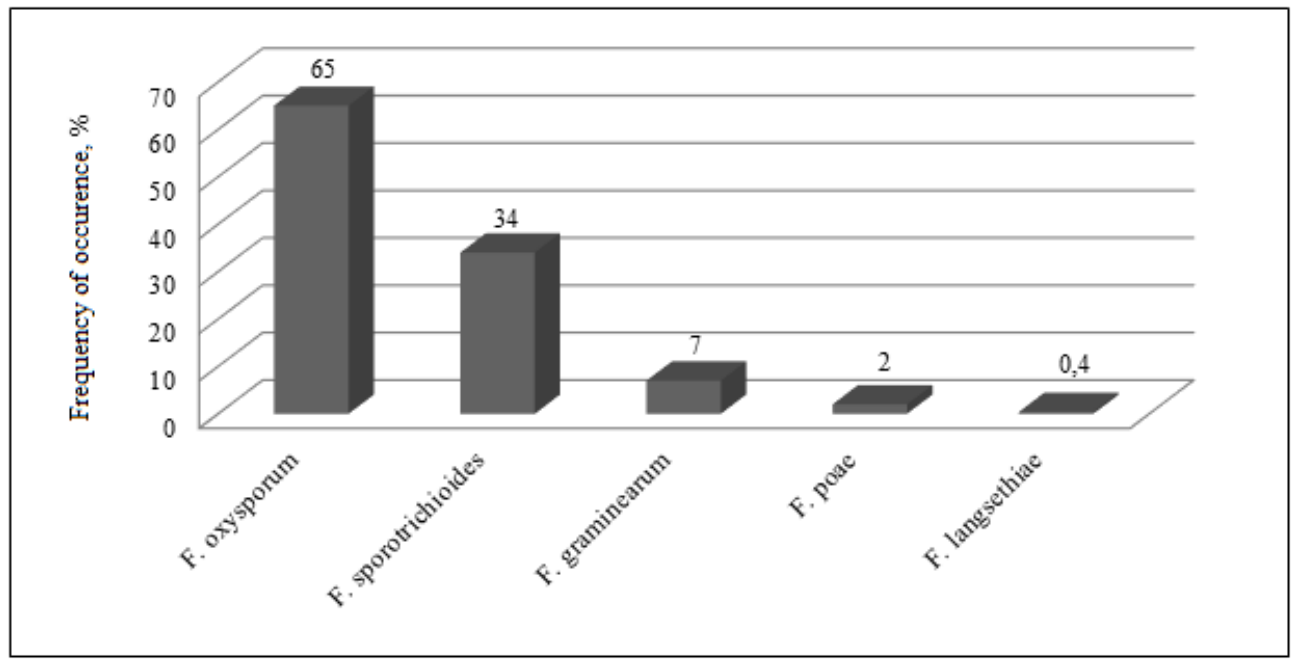

Fig. 3. The ratio of species of fungi of the genus Fusarium spp. on underground and near-ground organs of wheat in milk-wax ripeness phase.

Some species of fungi of the genus Fusarium are poorly controlled by modern preparations used for seed treatment. To assess the effectiveness of the studied fungicides, the indicator "preparation activity" was used [9].

Laboratory tests have shown that the pre-treatment of seed material with fungicides Zim 500 (carbendazim), Hype (triticonazole + prochlorase) and Oplot (diphenoconazole + 
tebuconazole) provided the largest diameter of the inhibition zone of fungus mycelium and, accordingly, the activity of the preparation (Table 1).

The use of the biological preparation Phytosporin-M (AS) (Bacillus subtilis + Trichoderma spp. + lysates of rhizospheric bacteria +20 L-amino acids $-5 \%+$ natural polysaccharides, phytohormones, vitamins) did not affect fungus growth and development, the effectiveness was at the control level. Joint use of biofungicide and a $50 \%$ reduced Bunker (tebuconazole) flow rate also turned out to be ineffective in restraining the growth of the phytopathogen.

The biological fungicide Phytosporin-M (AS) and its mixture with a chemical mordant in a reduced flow rate showed no deterrent effect on fusarium fungi, the activity index of the preparation was 1.0-1.7.

When testing mordants against fungi of the genus Fusarium spp. it turned out that in the inhibition zone of the micromycete, the absence of mycelium was noted only on the variant with carbendazim.

Table 1. The effect of mordants on fungi of the genus Fusarium Spp.when processing seeds of spring wheat of the Omskaya 36 variety.

\begin{tabular}{|c|c|c|c|c|}
\hline Variant & Active substance & $\begin{array}{l}\text { Preparation } \\
\text { dose }\end{array}$ & $\begin{array}{l}\text { Diameter of the } \\
\text { inhibition zone } \\
\text { of the } \\
\text { mycelium of } \\
\text { the fungus } \\
\text { Fusarium Spp., } \\
\text { mm } \\
\end{array}$ & $\begin{array}{c}\text { Preparation } \\
\text { activity }\end{array}$ \\
\hline Control & - & - & 0.3 & - \\
\hline Zim 500, CS & Carbendazim $500 \mathrm{~g} / 1$ & $11 / t$ & 22.4 & 7.5 \\
\hline Hype, CS & $\begin{array}{l}\text { Triticonazole } 20 \mathrm{~g} / 1+ \\
\text { prokhloraz } 60 \mathrm{~g} / 1\end{array}$ & $21 / t$ & 16.6 & 5.5 \\
\hline Oplot, VSK & $\begin{array}{c}\text { Difenoconazole } 90 \mathrm{~g} / 1+ \\
\text { tebuconazole } 45 \mathrm{~g} / 1\end{array}$ & $0.51 / \mathrm{t}$ & 15.7 & 5.2 \\
\hline $\begin{array}{c}\text { Phytosporin-M, } \\
\text { Zh (AS) + } \\
\text { bunker, VSK }\end{array}$ & $\begin{array}{l}\text { Bacillus subtilis, strain } 26 \mathrm{D} \\
+ \text { Trichoderma }+ \text { lysates of } \\
\text { rhizospheric bacteria }+20 \mathrm{~L}- \\
\text { amino acids }-5 \%+\text { natural } \\
\text { polysaccharides, } \\
\text { phytohormones, vitamins }+ \\
\text { tebuconazole } 60 \mathrm{~g} / 1 \\
\end{array}$ & $\begin{array}{c}11 / t+0.25 \\
1 / t\end{array}$ & 5.2 & 1.7 \\
\hline $\begin{array}{l}\text { Phytosporin-M, } \\
\text { Zh (AS) }\end{array}$ & $\begin{array}{c}\text { Bacillus subtilis, strain } \\
26 \mathrm{D}+\text { Trichoderma spp. }+ \\
\text { lysates of rhizospheric } \\
\text { bacteria }+20 \text { L-amino acids } \\
-5 \%+\text { natural } \\
\text { polysaccharides, } \\
\text { phytohormones, vitamins }\end{array}$ & $11 / t$ & 3.0 & 1.0 \\
\hline $\mathrm{LSD}_{05}$ & & & \multicolumn{2}{|c|}{5.5} \\
\hline
\end{tabular}

The seed material analyzed in the laboratory was sown in field experiments. The results of these studies are shown to compare the applicability of laboratory data with field data, and their reasonableness for making recommendations on protection measures.

The field germination of spring wheat in the experiment on the control without seed treatment was at the level of $77 \%$. An increase in the indicator by 4 percentage points was noted on variants with the treatment of seeds of the tank mixture Phytosporin-M (AS) + Bunker. On the other variants of the experiment, the density of shoots did not differ much from the control variant. It should be noted that the preparation Oplot delayed the 
appearance of shoots for a day, which was a consequence of a significant shortening of coleoptile.

The infection of wheat with root rot of mainly fusarium etiology in the control variant was $24.2 \%$, with disease prevalence of $84 \%$ (Table 2 ).

Table 2. - The effect of seed treatment preparations on field yield and wheat damage by root rot in the tillering phase, 2019-2020.

\begin{tabular}{|c|c|c|c|c|c|}
\hline \multirow[b]{2}{*}{ Variant } & \multicolumn{2}{|c|}{ Actual yield } & \multirow{2}{*}{$\begin{array}{c}\text { Economic } \\
\text { efficiency, \% }\end{array}$} & \multicolumn{2}{|c|}{$\begin{array}{c}\text { Root rot in the tillering } \\
\text { phase, } \%\end{array}$} \\
\hline & $\mathrm{c} / \mathrm{ha}$ & $\begin{array}{l}+/- \text { to } \\
\text { control }\end{array}$ & & $\begin{array}{c}\text { disease } \\
\text { developm } \\
\text { ent }\end{array}$ & $\begin{array}{c}\text { biological } \\
\text { efficiency of } \\
\text { the preparation }\end{array}$ \\
\hline $\begin{array}{l}\text { Control without seed } \\
\text { treatment }\end{array}$ & 19.0 & - & - & 24.2 & - \\
\hline Oplot 0.5 1/t & 22.0 & 3.0 & 14 & 3.3 & 86 \\
\hline $\begin{array}{l}\text { Phytosporin-M, Zh (AS) } \\
11 / \text { t }\end{array}$ & 20.5 & 1.5 & 7 & 11.8 & 51 \\
\hline $\begin{array}{l}\text { Phytosporin-M, Zh (AS) } \\
11 / \mathrm{t}+\text { Bunker } 0.251 / \mathrm{t}\end{array}$ & 19.9 & 0.9 & 5 & 11.4 & 53 \\
\hline LSD $_{05}$ & \multicolumn{3}{|c|}{1.38} & & \\
\hline
\end{tabular}

The biofungicide protected plants by $51-53 \%$ both in pure form and in a mixture with a chemical mordant. From the data obtained, it can be seen that the laboratory efficiency is slightly lower than the field one. This can be explained by the rather high suppressiveness of the soil (the ability to self-regulate the phytosanitary state of the soil substrate), which amounted to $60 \%$ for this phytopathogen, due to a sufficiently large number of bacteria 13 million. CFU/g of soil, especially of the bacillary form and actinomycetes 1.5 million. $\mathrm{CFU} / \mathrm{g}$ of soil that have a depressing effect on fungi of the genus Fusarium spp.

The Oplot mordant showed high efficiency, where the intensity of the disease decreased by $86 \%$.

The economic efficiency of seed protection over the years of research ranged from 5 to $14 \%$. A good level of reliable increase in productivity was noted on the variant of using the Oplot preparation. The combination of active substances diphenoconazole $90 \mathrm{~g} / \mathrm{l}$ with tebuconazole $45 \mathrm{~g} / \mathrm{l}$ successfully reduced the damage of wheat by root rot of the above etiology, which positively affected the productive bushiness of plants and provided an increase in crop yield by $3 \mathrm{c} / \mathrm{ha}$ or $14 \%$.

\section{Conclusion}

Thus, under the current conditions, there has been a progressive development of fungi of the genus Fusarium spp. both on seed material and on vegetating plants. To reduce the spread and development of the phytopathogen, it is necessary to apply a set of measures. One of which is pre-sowing seed treatment. Nevertheless, not all the proposed preparations are equally effective in suppressing the development of the fungus of the genus Fusarium spp.. In laboratory conditions, it was found that the chemical seed mordant Oplot (difenoconazole + tebuconazole), Zim ( carbendazim), Hype (triticonazole + prochlorase) were distinguished by high activity from 5.2 to 7.5 units. The use of the biological fungicide Phytosporin-M (AS) in its pure form or together with a reduced rate of consumption of a chemical mordant (tebuconazole) showed no or low inhibition of the development of the fungus mycelium. Nevertheless, in the field, their use against the background of high soil suppressiveness provided plant protection by $51-53 \%$. 
Based on the results obtained, it is possible to recommend agricultural producers to choose a particular fungicide for seed protection not only on the basis of the phytosanitary condition of the seeds, but also on the basis of the "soil health" indicator.

\section{Acknowledgment}

I express my gratitude to the staff of the laboratory of plant growth regulators and plant protection for their help in conducting experiments and preparing the material.

\section{References}

1. N. Gubareva, Agrarian sector 4, 74-75 (2015)

2. T.Yu. Gakkaeva, F.B. Gannibal, O.P. Gavrilova, Protection and quarantine of plants 1, 37-40 (2012)

3. S.Yu. Lviv, A.V. Yaitskikh, Protection and quarantine of plants 2, $42-44$ (2014)

4. I.N. Porsev, Adaptive phytosanitary technologies of cultivation of agricultural crops in the conditions of the Trans-Urals, 230 (Shadrinsk, 2009)

5. E.Yu. Toropova, O.A. Kazakova, I.G. Vorobyeva, M.P. Selyuk, Protection and quarantine of plants 9, 23-26 (2013)

6. The list of pesticides and agrochemicals allowed for use on the territory of the Russian Federation for 2020, LLC Listerra Publishing House, 920 (2020)

7. V.I. Bilai, Fusarium, 442 (Kiev, Naukova dumka, 1977)

8. N.M. Pidoplichko, Naukova dumka 2, 300 (1977)

9. V.V. Chekmarev [et al.] Methodology for determining the fungicidal activity of chemical preparations and other agents against plant pathogens - fungi of the genus Fusarium. - Tambov: Publishing House of TSU n.a. G.R. Derzhavin. 45 (2013).

10. V.V. Chekmarev, Agricult. Sci. «Colloquium-journal», 5 (57), 53-54 (2020)

11. E.Yu. Toropova, A.P. Glinushkin, M.P. Selyuk, O.A. Kazakova, A.V. Ovsyankina, Rus. Agricult. Sci. 44 (3), 241-244 (2018)

12. E.Yu. Toropova, I.G. Vorobyova, M.A. Mustafina, M.P. Selyuk, Agrochemistry 5, 76$82(2019)$ 